\title{
The effects of dietary vitamin $\mathrm{C}$ and Citrus Sinensis peel on growth, hematological characteristics, immune competence, and carcass characteristics in broilers exposed to heat stress
}

\author{
Y.S. Abdulameer \\ Department of Animal and Poultry Public Health, Faculty of Veterinary Medicine, Al Qasim Green University, Babylon, Iraq, \\ Email: abdulameer@ut.ac.ir,yha_sabir@yahoo.com
}

(Received March 19, 2018; Accepted April 19, 2018)

\begin{abstract}
This study investigated the role of vitamin C and Citrus Sinensis peel (sweet orange peel (Sop)) on growth, carcass characteristics and health status in 160 one day old broiler chickens (Ross308) which were randomly divided into four equal groups consisting 4 pens. Each pen having 10 birds ( 5 male and 5 female) for 35 days. All chicks were exposed to heat stress $\left(33^{\circ} \mathrm{C}\right)$ during all the experimental period (35 days). Group one considered as control, groups 2, 3, 4 were given feed containing vitamin C (500ppm/ feed), sweet orange peel (Sop) (1,2\% respectively). Sop $2 \%$ significantly increased average body weight gain and feed intake during the grower period (16-28) $(\mathrm{P}<0.05)$. The birds fed Sop $2 \%$ during the whole experimental period had higher FI and greater feed conversion ratio $(\mathrm{P}<0.05)$ compared to the other groups. The mortality rate tended to be the lowest in the birds fed the feed additives $(\mathrm{P}<0.05)$. The relative weight of internal organs, blood profiles pictures were not affected by Sop with two tested levels $(\mathrm{P}<0.05)$ or vitamin $\mathrm{C}$ compared with the control group. Broiler fed vitamin $\mathrm{C}$ or Sop levels had greater primary and secondary antibody responses to sheep red blood cells (SRBC) and against phytohemagglutinin (PHA-P) antigen compared with those in the control group $(\mathrm{P}<0.05)$. Sop and vitamin $\mathrm{C}$ increased antibodies titer against Newcastle disease during the secondary antibody response $(\mathrm{P}<0.05)$. Overall, Sop as feed additive improved immune responses in broiler chickens under heat stress. Also the result indicate that the Sop $2 \%$ during the grower period had a positive effect on growth performance of broiler chickens under heat stress.
\end{abstract}

Keywords: Broiler, Blood Biochemical Profile, Carcass Trait; Sweet Orange Peel; Production Available online at http://www.vetmedmosul.com

$$
\begin{aligned}
& \text { تأثير فيتامين ج وقثور البرتقال كأضافات غذائية على اداء النمو و الصفات الاموية والكفاعة }
\end{aligned}
$$

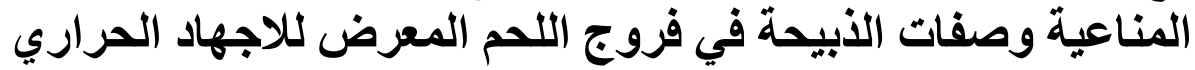

$$
\begin{aligned}
& \text { يحيى صباح عبد الامير } \\
& \text { فرع الصحة العامة البيطرية، كلية الطب البيطري، جامعة القاسم الخضر اء، بابل، العر اق }
\end{aligned}
$$

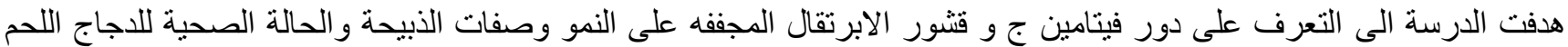

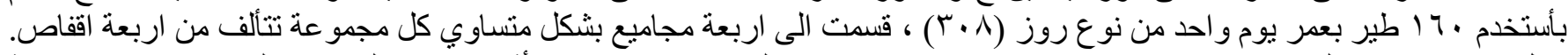

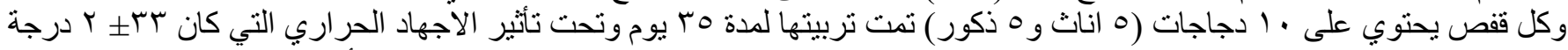

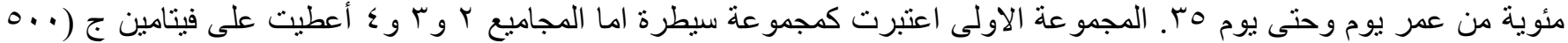

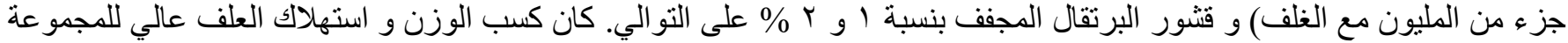

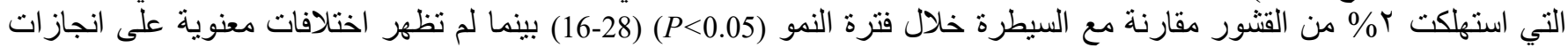




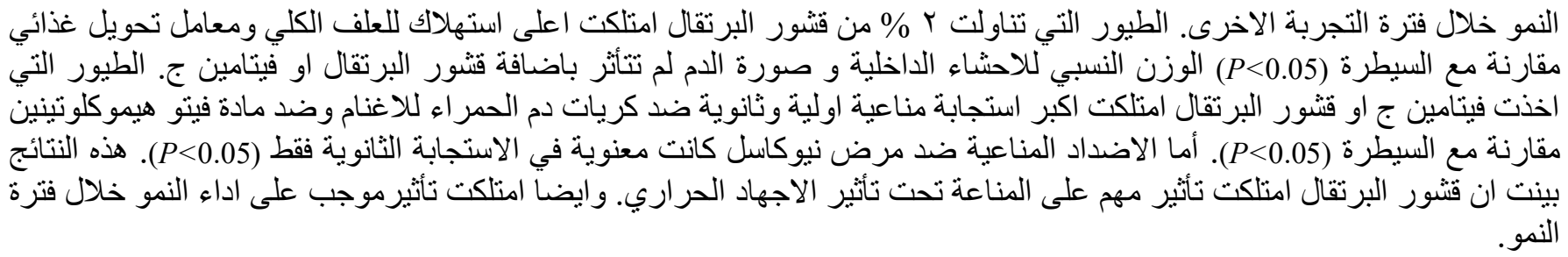

\section{Introduction}

The effects of thermal stress (TS) on chickens have been widely explored due to their relation to economic losses and animal performance retardation. Modern broiler chickens strains have greater sensitive to high temperature than old strain (1). A high temperature is one of the major stressors linked to economic losses to the poultry industry (2). It causes bad growth performance (3), immune depression (4), and high fatal rate (5). The optimum living temperature of broiler chickens ranges between $33^{\circ} \mathrm{C}$ to $21{ }^{\circ} \mathrm{C}$ depending on the age. The physiological, immunological and productive status are influenced by a temperature-humidity index (6). In broiler chicken, thermal stress TS symptoms include panting of breath, uncomfortable, and loss of appetite (7). Additionally, heatstressed broiler chickens usually suffer a state of metabolic disorders (8). Studies have reported that growth performance of thermal-stressed broilers is decreased by $>$ $14 \%$ between 1 to 40 days of age (9) and their results revealed that the TS, is one of the major agents leading to decrease feed consumption by $22 \%$ between 1 - 42 days of age in broiler chickens subjected to $35{ }^{\circ} \mathrm{C}$. Until 2006, it was known that considerable attention has been paid to chemical materials and antibiotics that promote the metabolic ecosystem resulting in alleviating thermal stresses (10). Also, several types of nutritional components have been used to alleviate TS, including vitamin C (11), niacin (12), K2SO4 and Gamma-AminoButyric Acid (13). Vitamin $\mathrm{C}$ is a major antioxidant that acts as scavenger agent for removing free radical roots produced by thermal condition (14). The skin forms one-fourth of the fruit and it can be used as anti thermal stress because its components contain vitamin C, energy, and high level of phenol (15). These components participate in anaerobic glycolysis and tissue respiration activities. Also, they play important roles in anti-TS (16).Under normal condition, the skin of sweet orange fruit can increase a growth performance, daily feed intake (DMI), carcass yield, and improve a meat quality (17). Because of, the great attention on using natural products as feed additive instead of chemical products in broiler diets, we thought that the Sop and ascorbic acid may be able to reduce antibiotic and adverse effects of heat stress. Therefore, the current study was designed to use vitamin $\mathrm{C}$ and Sop as feed additives, as a potential antistress factor to improve the growth performance, carcass characteristics, and blood profiles in broiler chickens under thermal stress.

\section{Material and methods}

\section{Birds and experimental treatments}

A completely randomized control design was conducted to explained the role of vitamin C and Citrus Sinensis peel (sweet orange peel (Sop)) on growth and health status of broiler chicken in to heat stress condition. One hundred and sixty, one-day-old broiler chickens (Ross 308) were purchased from a commercial broiler hatchery (Babylon Company). The broilers were housed in suitablesized floor pens (16 pens; 5 males and 5 females per pen; $0.11 \mathrm{~m}^{2} /$ boiler chicks). The floor pen was covered with a 7$\mathrm{cm}$ layer of wood shaving and provided with one water and one feeder. The ambient temperature in broiler's pen was $33{ }^{\circ} \mathrm{C} \pm 2$ on day 1 until day 35 of age. The relative humidity was $60 \%$ during the study. The light program was $23 \mathrm{hrs}$ light $/ 1 \mathrm{hrs}$ darkness. The broiler chicks were weighed and divided into 4 groups. Each group consisted of 4 pens. The experimental groups were assigned to form the first group 1 (T1) (control): basal diet without any feed additives. Second Group 2 had broilers which fed on basal diet contained $5 \mathrm{ppm} /$ feed of vitamin C (10\%) (Pars-Daro Company, Gorgan, Iran) as feed additive from day one to day 35 of age. Third group was the broiler chicks that fed a basal diet contained Sop $1 \%$ as feed additive from one day old to 35 days of age. Fourth group consisted of broiler chicks that received a basal diet with Sop $2 \%$ as feed additive from one day old to 35 days of age. The feed and water were provided ad libitum. The nutritional requirements of broiler chickens were formulated according to a two-phase feeding program on a starter diet (1-21 days) and a finisher diet ( 21 to 35 days of age). The ingredient compositions of basal diets were formulated to meet the nutritional requirements of broiler chicken Ross 308 based on Boiler Nutrition Specification (18) (Table 1). All the broiler chicks were vaccinated according the common vaccinated programs in Iraq (Table 2). 
Table 1: Ingredients and nutrient level of basal diets Item $(\% \text {, as fed basis })^{1}$

\begin{tabular}{|c|c|c|}
\hline Ingredients $\%$ & $\begin{array}{c}\text { Starter } \\
(1-21 \mathrm{~d})\end{array}$ & $\begin{array}{l}\text { Finisher } \\
(22-35 d)\end{array}$ \\
\hline Corn & 58.50 & 63.10 \\
\hline Soybeanmeal & 35.99 & 31.39 \\
\hline Vegetable oil & 1.25 & 2.21 \\
\hline Dicalcium phosphate & 1.75 & 1.25 \\
\hline Lime stone & 1.57 & 1.39 \\
\hline Lysine-Hcl & 0.02 & 0.03 \\
\hline Dl-Methionine & 0.37 & 0.23 \\
\hline Sodium chloride & 0.25 & 0.20 \\
\hline Mineral-vitamin premix ${ }^{¥}$ & 0.30 & 0.21 \\
\hline \multicolumn{3}{|c|}{ Nutrients composition } \\
\hline Metabolizable energy $(\mathrm{kcal} / \mathrm{kg})$ & 2,960 & 3,085 \\
\hline Crude protein & 22.00 & 20.2 \\
\hline Calcium\% & 1.00 & 0.94 \\
\hline Available phosphorus\% & 0.71 & 0.63 \\
\hline Methionine + cysteine $\%$ & 0.92 & 0.77 \\
\hline Lysin \% & 1.13 & 1.05 \\
\hline Threonin & 0.93 & 0.79 \\
\hline \multicolumn{3}{|c|}{$\begin{array}{l}\text { Mineral-vitamin premix provided the following per } \\
\text { kilogram of diet:vitamin A, 9,000 IU; vitamin D3, 2,100 } \\
\text { IU; vitamin E, } 30 \mathrm{mg} \text {; nicotinic acid, } 30 \mathrm{mg} \text {; vitamin B12, } \\
0.12 \mathrm{mg} \text {; calcium pantothenate, } 10 \mathrm{mg} \text {; vitamin } \mathrm{K} 3,5 \mathrm{mg} \text {; } \\
\text { thiamine, } 1.1 \mathrm{mg} \text {; riboflavin, } 4.5 \mathrm{mg} \text {; vitamin } \mathrm{B} 6,2.0 \mathrm{mg} \text {; } \\
\text { folic acid, } 0.5 \mathrm{mg} \text {; biotin, } 0.5 \mathrm{mg} \text {; Fe, } 50 \mathrm{mg} \text {; Cu, } 10 \mathrm{mg} \text {; } \\
\text { Mn, } 70 \mathrm{mg} \text {; } \mathrm{Zn}, 50 \mathrm{mg} \text {; I, } 1.0 \mathrm{mg} \text {; Se, } 0.3 \mathrm{mg} \text {; butylated } \\
\text { hydroxytoluene, } 150 \mathrm{mg} \text {. }{ }^{1} \text { Estimated from NRC (1994) } \\
\text { composition table. }\end{array}$} \\
\hline
\end{tabular}

Table 2: Vaccination program applied during the experiment

\begin{tabular}{lcc}
\hline Types & $\begin{array}{c}\text { Age of broiler } \\
\text { chicks }\end{array}$ & $\begin{array}{c}\text { Route of } \\
\text { administration }\end{array}$ \\
\hline $\begin{array}{l}\text { IB (infectiousbronchitis) } \\
\text { (GeneraCompany, Croatia) }\end{array}$ & 8 & Orally \\
$\begin{array}{l}\text { ND-Hitchiner B1 (Genera } \\
\text { Company, Croatia) }\end{array}$ & 12 & Intraocular \\
$\begin{array}{l}\text { ND-La Sota strain } \\
\text { (Nobilis }{ }^{\circledR} \text { ND Clone 30, }\end{array}$ & 18 & Intraocular \\
Intervet) & & \\
\hline
\end{tabular}

\section{Data Collections}

Growth performance

Observations on body weight gain (BWG) (g), feed intake (g) (FI), and feed conversion ratio (FCR) (feed / gain) were recorded on a pen basis from day 1 to 14,15 to 28 days, and 29 to 35 days of age. The feed intake was recorded by subtracting weekly remaining feed from offered feed. Mortality rate were recorded on a daily basis. Any dead bird was weighed, and the FCR and FI were adjusted accordingly.

\section{Determination of blood biochemical parameters and organs weight}

At the end of the experiment ( 5 weeks), after $9 \mathrm{hrs}$ starvation, 2 chickens from each pen (female) were selected randomly and weighed. The blood samples were collected via jugular vein and put in labeled tubes with and without anticoagulants and centrifuged at $2500 \mathrm{rpm}$ for $15 \mathrm{~min}$ at 25 ${ }^{0} \mathrm{C}$ to obtain serum and the serum samples were kept in eppendrof tubes at $-15^{0} \mathrm{C}$. The biochemical tests: Total protein, total cholesterol, blood urea, serum creatinine and triglyceride levels were evaluated using Reflotrone plus analyzer (Roche, USA). While the heparinzed tubes were used for measuring white blood cells (WBC), red blood cells (RBCs), hemoglobin ( $\mathrm{Hb})$ and hematocrit (HCL) using automatic blood analyzer (boehringer, Mannhe, Germany) the hetrophils to lymphocytes ratio $(\mathrm{H} / \mathrm{L})$, were measured by Gimsa stain methods. All samples were analyzed by averaging the triplicate of a single sample, error is reduced. Thereafter, the previously selected broiler chickens were slaughtered by halal method. The weights of hot carcass, and internal organs e.g. liver, spleen, heart, Bursa, and intestinal weight were measured expressed as a percentage of the live body. The intestinal length was also recorded.

\section{Immune competence measurements}

On days 18, 25 of age, two female broilers from each pen were selected and injected with $0.2 \mathrm{ml}$ of $0.5 \%$ sheep red blood cell suspension in breast muscle. At 18, 25, and 32 days of age, blood samples were taken from jugular vein. Serum was collected by centrifugation $(2500 \mathrm{ppm}, 10$ min at $25{ }^{\circ} \mathrm{C}$ ) and stored at $-15^{\circ} \mathrm{C}$ for measuring antibodies titer against sheep red blood cell (SRBC) and Newcastle viral disease (NDV) by HI as referred previously by (19). HI was expressed by $\log 2$ of the reciprocal of the highest dilution giving visible hemagglutination.

\section{Statistical analysis}

The collected data were subjected to Anova procedures for a completely randomized design using the SPPS software (20). The mean values were compared by LDS tests at $\mathrm{P}<0.05$. The experimental unit differed according to the parameter that was measured. For performance characteristics, the experimental unit was pen, whereas individual chick data were used for blood biochemical parameters. The mathematical model was as follow:

$X_{i j}=U+T_{i}+E_{i j}$. 
Where, $\mathrm{X}_{\mathrm{ij}}=$ value observed in each group, $\mathrm{U}=$ is the mean of the observation, $\mathrm{T}_{\mathrm{i}}=$ the effect of feed addives, $\mathrm{E}_{\mathrm{ij}}=$ the effect of experimental error.

\section{Results and discussion}

\section{Growth performance}

As shown in Table 3, sweet orange peel (Sop) with level $2 \%$ improved body weight gain (BWG) and feed intake (FI) of broiler chicks during the grower (15-28 days) $(\mathrm{P}<0.05)$, but no statistical effects were shown during the other experimental periods. Treatment with Sop (2\%) enhanced overall FI $(\mathrm{P}<0.05)$, (during the whole period 135 days) compared with the control group. Moreover, chickens received high level $2 \%$ of Sop had inferior feed conversion ratio (FCR) than Control group $(\mathrm{P}<0.05)$. The mortality rate was significantly reduced when broilers were given diet containing $2 \%(\mathrm{P}<0.05)$. Considerable attention has been focused in recent years on the natural products in animal feed. They have been shown that their effects can reduce antibiotic growth promoters in animal production (21). The main purpose of the use of peel of sweet orange in this study is to reduce the chemical anti stress materials under heat stress in broiler chickens. In the current study, the results showed that FI, and BWG during the grower period and mortality rate in bird fed Sop $2 \%$ were improved compared with the control group. It was previously revealed that BWG, FI were enhanced in broiler chicks fed diets contained 1 or $2 \%$ of Sop (22). In the present study, stressed broiler chickens in the Sop levels and vitamin C treatment gained more $\mathrm{BW}$ and FI than did stressed broilers in the control group during grower and whole period of experiment. Dietary Sop improved broiler growth performance at the levels less than $5 \%$ (16). The similar trend was reported by (22), who used two levels of Sop $1 \%$ and $2 \%$ as feed additive in broiler diet under normal condition. (23) who explained that the Sop supplementation at levels of 10 to $50 \%$ did not change the mean of BWG, FI, and FCR during starter and finisher period. Furthermore, $(16,17)$ who reported that the Sop levels of 3 to $5 \%$ as a feed additive in broiler chickens had negative effects on growth performances. $(24,25)$ explained that the negative effects of high dose of Sop on growth production in broiler chicken attributed to high crud fiber and pectin presented in the Sop (26). The fiber and Pectin have a deteriorating effect on GIT through increasing viscosity within intestinal tract which lower the digestive enzymes (27). No significant effects were seen in growth performances of broilers during starter and finisher among experimental treatments. These results are comparable with those reported by other researchers $(22,23)$. Furthermore, $(28,29)$ evinced a no significant effect in the mean body weight at starter period of age in the broiler chickens receiving Sop in their diet $(0.4$ or $0.8 \mathrm{~g} / \mathrm{kg}$ feed) as compared with control group. The no significant effect of orange peel powder on growth performances in the 35-day of rearing period is unknown. A biological effect of Sop does not appear to play a major role, since overall feed conversion ratio was not affected with the low dose, while was inferior with the high dose $2 \%$. As result of the increase of the fiber and pectin in broiler's diet at the high dose of Sop, slow enzymatic secretion can result in an increase FI for obtaining required energy. On the contrary, feeding graded levels 2. 3. $5 \%$ of dried lemon peels decreased daily feed intake in broiler chickens $(26,30,31)$. It is important to note that, there are fluctuated results of Sop on growth performances. Nevertheless, the efficacy of vitamin $\mathrm{C}$ or Sop agent may be influenced by several factors, such as differences in the levels, age, feed components, and farm hygiene.

\section{Carcass traits}

The effects of treatments on carcass traits of broiler chickens are shown in Table 4. Internal organs (liver, heart, and Bursa) were not affected by treatments. Meanwhile, the inclusion of $1 \%$ Sop in the diet recorded the highest relative weight of spleen $(\mathrm{P}<0.05)$. Similarly, no obvious effect of treatments was found in terms of relative intestinal weight and intestinal length, although, the relative weight of carcass yield tended to decrease due to dietary addition of Sop $2 \%(\mathrm{P}<0.05)$. No favorable effects were observed in the relative weight of internal organs except in spleen (Table 4). The current results were confirmed by $(32,33)$ who showed no obvious effect of Sop on relative weight of liver, gizzard, heart and bursa. Furthermore, our results confirmed that the Sop at levels of 1 to $2 \%$ did not have any side effects on internal organs. (34) showed that the Sop did not affect lymphoid organs. On the basis of these effects of Sop on spleen, may indicate an enhancement of immune function. The carcass yield was reduced with the increase of Sop level of $2 \%$. This result was in agreement with research articles of (22). Increasing fiber in the diet with the high dose of Sop $2 \%$ is an acceptable mechanism of the reduction in carcass yield.

\section{Hematological parameters}

The effects of treatments on blood biochemical indices of 35-days-old broilers are revealed in Table 5. The serum concentration of T.P, serum triglyceride, blood urea, and creatinine concentrations were not significantly affected by treatments at 35 days of age. In addition, the blood hematology (WBC, RBC, HB, HCT and $\mathrm{H} / \mathrm{L}$ ratio) was not influenced by dietary treatments which are showed in Table 6. These observations showed that inclusion of Sop levels and vitamin $\mathrm{C}$ did not change biochemical parameters (T.P. cholesterol, creatinine and blood urea) or hematological traits (WBC, $\mathrm{RBC}, \mathrm{H} / \mathrm{L}$ ratio, $\mathrm{Hb}$ and $\mathrm{Hct}$ ). These results were in line with findings of (22) who found that sweat 
orange peel with different levels from 0.5 to $2 \%$ as feed additives of broiler chickens had no effects on glucose, cholesterol, and liver enzymes. Also, they revealed that high dose of Sop could change the low and high density lipoprotein. (35) revealed that Sop up to level of $40 \%$ as feed additive of broiler chicken did not effect on blood biochemical parameters (T.P, cholesterol and albumin). The vitamin $\mathrm{C}$ also had no effect on blood profiles at level 250 $\mathrm{g} / \mathrm{kg}$ feed (10). (35) have concluded that, the offer of sweet orange waste up until $8 \%$ in the ration, the haematological and serum biochemical indices (measured variables were erythrocytes, hemoglobin, hematocrit, leukocyte) had no negative impact. Incontrast to our results, (36) found that Sop as feed additives had beneficial effects on reducing cholesterol and triglyceride and on increasing total protein and globulin, but no effect on glucose.

Table 3: productive performances for broiler ${ }^{1}$ at different periods as influenced by Vit $\mathrm{C}$ and different levels of Sop

\begin{tabular}{|c|c|c|c|c|c|c|}
\hline \multirow[t]{2}{*}{ Item } & \multicolumn{6}{|c|}{ Treatments $^{2}$} \\
\hline & Control & vit. $\mathrm{C}$ & Sop 1\% & Sop $2 \%$ & SEM & $P$ value \\
\hline \multicolumn{7}{|c|}{ BWG (g/bird) } \\
\hline $1-14 d$ & 440 & 440 & 452 & 448 & 4.6 & 0.7 \\
\hline $15-28 \mathrm{~d}$ & $852.2^{\mathrm{b}}$ & $942.5^{\mathrm{ab}}$ & $916.3^{\mathrm{ab}}$ & $1022^{\mathrm{a}}$ & 24.9 & 0.01 \\
\hline $29-35 d$ & 465 & 392 & 393.7 & 337 & 26.5 & 0.4 \\
\hline $1-35 d$ & 1761 & 1793 & 1771 & 1737 & 25.2 & 0.9 \\
\hline \multicolumn{7}{|c|}{ Feed intake (g/bird) FI } \\
\hline $1-14 d$ & 458.7 & 489 & 500 & 500 & 13 & 0.7 \\
\hline $15-28 \mathrm{~d}$ & $1657.3^{\mathrm{c}}$ & $1770^{\mathrm{b}}$ & $1831^{\mathrm{b}}$ & $1967^{\mathrm{a}}$ & 31 & 0.00 \\
\hline $29-35 d$ & 1025.5 & 1000 & 1025 & 1151 & 29.2 & 0.26 \\
\hline $1-35 \mathrm{~d}$ & $3102^{\mathrm{c}}$ & $3350^{\mathrm{b}}$ & $3380^{\mathrm{b}}$ & $3577^{\mathrm{a}}$ & 56 & 0.009 \\
\hline \multicolumn{7}{|c|}{ Feed conversion ratio (feed:gain) } \\
\hline $1-14 d$ & 1.04 & 1.1 & 1.13 & 1.12 & 0.03 & 0.8 \\
\hline $15-28 \mathrm{~d}$ & 1.93 & 1,95 & 1.79 & 1.94 & 0.03 & 0.5 \\
\hline $29-35 d$ & 2.2 & 2.9 & 2.8 & 2.9 & 0.22 & 0.7 \\
\hline $1-35 d$ & $1.7^{\mathrm{a}}$ & $1.8^{\mathrm{ab}}$ & $1.9^{\mathrm{ab}}$ & $2^{b}$ & 0.01 & 0.04 \\
\hline \multicolumn{7}{|l|}{ PEI } \\
\hline 35 days & 266 & 275 & 266 & 250 & 9.2 & 0.4 \\
\hline \multicolumn{7}{|c|}{ Mortality rate } \\
\hline 35 days & $0.93^{\mathrm{a}}$ & $0.33^{\mathrm{b}}$ & $0.3^{\mathrm{b}}$ & $0.15^{\mathrm{b}}$ & 0.12 & 0.04 \\
\hline
\end{tabular}

Table 4: Effect of vitamin C and sweet orange peel on the carcass characteristics of broiler ${ }^{1}$

\begin{tabular}{lcccccc}
\hline Item & \multicolumn{7}{c}{ Treatments } \\
\cline { 2 - 7 } & Control & vit. C & Sop 1\% & Sop 2 \% & SEM & P value \\
\hline Carcass yield percentage & $73.2^{\mathrm{b}}$ & $75.7^{\mathrm{b}}$ & $73.9^{\mathrm{b}}$ & $68.7^{\mathrm{a}}$ & 0.78 & 0.008 \\
Liver (\%) & 2.69 & 2.44 & 2.6 & 2.6 & 0.05 & 0.09 \\
Heart (\%) & 0.52 & 0.50 & 0.52 & 0.54 & 0.01 & 0.6 \\
Spleen (\%) & $0.12^{\mathrm{b}}$ & $0.14^{\mathrm{ab}}$ & $0.18^{\mathrm{a}}$ & $0.16^{\mathrm{ab}}$ & 0.08 & 0.05 \\
Bursa & 0.087 & 0.067 & 0.089 & 0.082 & 0.004 & 0.4 \\
Intestinal weight \% & 6.7 & 7.52 & 7.1 & 6.2 & 0.18 & 0.06 \\
Intestinal length (cm) & 205.5 & 228.5 & 231.2 & 225 & 4.9 & 0.2 \\
\hline a-b
\end{tabular}

${ }^{\mathrm{a}-\mathrm{b}}$ values with different small letter superscripts within the same row indicate significant differences, ${ }^{1}$ Values are the means of four pens with 10 birds per pen, ${ }^{2}$ control: basal diet, vit C : basal diet $+500 \mathrm{mg}$ vitamin C / $\mathrm{kg}$ feed (500 ppm); Sop $1 \%$ : basal diet $+1 \%$ of Citrus sinensis as feed additive ; Sop $2 \%$ : basal diet $+2 \%$ of Citrus sinensis as feed additive. 
Table 5: Effect of vitamin $\mathrm{C}$ and sweet orange peel on the parameter of biochemical indices of broiler ${ }^{1}$

\begin{tabular}{lcccccc}
\hline Item & \multicolumn{7}{c}{ Treatments $^{2}$} \\
\cline { 2 - 7 } & Control & vit. C & Sop 1\% & Sop 2 \% & SEM & P value \\
\hline TP $(\mathrm{g} / \mathrm{dl})$ & 4.7 & 4.9 & 5.9 & 5.5 & 0.17 & 0.15 \\
Cholesterol $\mathrm{mg} / \mathrm{dl}$ & 134 & 122.3 & 134.5 & 130.7 & 3 & 0.5 \\
Triglyceride $(\mathrm{mg} / \mathrm{dl})$ & 194 & 192 & 209 & 178.2 & 7.2 & 0.7 \\
Blood urea $(\mathrm{mg} / \mathrm{dl})$ & 16.37 & 17.0 & 11.59 & 17.7 & 1.53 & 0.5 \\
Creatinine $(\mathrm{mg} / \mathrm{dl})$ & 0.5 & 0.5 & 0.5 & 0.5 & 0.00 & 0.00 \\
\hline
\end{tabular}

${ }^{a-b}$ values with different small letter superscripts within the same row indicate significant differences ${ }^{1},{ }^{1}$ values are the means of 4 pens of two birds per pen ( 8 birds / treatment), SEM : Standard error mean, ${ }^{2}$ control: basal diet, vit C : basal diet $+500 \mathrm{mg}$ vitamin C / $\mathrm{kg}$ feed (500 ppm); Sop 1\%: basal diet $+1 \%$ of Citrus sinensis as feed additive; Sop $2 \%$ : basal diet $+2 \%$ of Citrus sinensis as feed additive.

Table 6: Effect of vitamin $\mathrm{C}$ and sweet orange peel on the parameter of haematology of broiler ${ }^{1}$

\begin{tabular}{lcccccc}
\hline \multirow{2}{*}{ Item } & \multicolumn{7}{c}{ Treatments $^{2}$} \\
\cline { 2 - 7 } & Control & vit. C & Sop 1\% & Sop 2 \% & SEM & P value \\
\hline $\mathrm{RBC}\left(1 \mathrm{o}^{6} / \mu \mathrm{L}\right)$ & 2.67 & 2.61 & 2.73 & 2.49 & 0.068 & 0.6 \\
$\mathrm{WBC}($ thousand $/ \mu \mathrm{L})$ & 76.9 & 79.4 & 72.3 & 72.4 & 1.3 & 0.1 \\
$\mathrm{Hb}(\mathrm{g} / \mathrm{dl})$ & 10.8 & 11 & 10.9 & 10.42 & 0.42 & 0.8 \\
$\mathrm{HCL} \%$ & 31.1 & 30.2 & 31.2 & 28 & 0.82 & 0.65 \\
Heterophils/ Lymphocytes ratio & 0.27 & 0.10 & 0.08 & 0.13 & 0.05 & 0.5 \\
\hline
\end{tabular}

${ }^{a-b}$ values with different small letter superscripts within the same row indicate significant differences, ${ }^{1}$ values are the means of 4 pens of two birds per pen ( 8 birds / treatment), SEM : Standard error mean, ${ }^{2}$ control: basal diet, vit C : basal diet $+500 \mathrm{mg}$ vitamin C / $\mathrm{kg}$ feed (500 ppm); Sop 1\%: basal diet $+1 \%$ of Citrus sinensis as feed additive ; Sop $2 \%$ : basal diet $+2 \%$ of Citrus sinensis as feed additive.

\section{Immune competence}

The effect of dietary treatments on humeral and cell mediate immune responses are explained in Table 7. Antibodies titer against NDV and SRBCs in the treated broiler chicks with Sop levels were higher at the primary and secondary response $(\mathrm{P}<0.05)$ compared with those in the control group. The highest web- toe thickness response against phytohemaglutinine was obtained in the broilers received feed additives $(\mathrm{P}<0.05)$. Sop is major sources of vitamin $\mathrm{C}$, hesperidine and poly phenols. These substances have potent ability to reduce free radical roots in the body and reduce oxidants in the body cells $(15,37,38)$. It is proven that some herbal components can modify the immune function $(39,40)$. In our experiment, it was found that Abs titer against SRBCs and against NDV were affected by Sop levels. In a previous research, (34) showed that by adding Sop extract at levels of 1000 to $1250 \mathrm{ppm}$, the Abs titer against NDV and SRBCs was increased $(\mathrm{P}<0.05)$. This increase in $\mathrm{Ab}$ titers is due to the flavonids presented in Sop causing stimulation of immune organs. The cell mediate immunity (web toe thickness) was significantly increased with the Sop levels and vitamin C.
The fibers contained in sop have an ability to promote phygocytosis and raise the interleukins, interferon $¥$ secretion (41).

\section{Conclusion}

Overall, Sop as feed additive improved immune responses in broiler chickens under heat stress. However, since the apparent impact on growth performances was only seen at the grower period when broilers fed the Sop $2 \%$ under heat condition, further research is needed to test the efficacy of Sop as a natural growth promoter under heat condition.

\section{Disclosure of conflict of interest}

The authors have declared that there is no conflict of interest.

\section{Statement of ethical approval}

All experimental steps used in the present study worked according to the guidelines were approved by the Animal Ethics Committee of Babylon University. 
Table 7: Effect of vitamin $\mathrm{C}$ and sweet orange peel on the parameter of the immune responses of broiler ${ }^{1}$

\begin{tabular}{lcccccc}
\hline Item & \multicolumn{5}{c}{ Treatments $^{2}$} \\
\cline { 2 - 7 } & Control & vit. C & Sop 1\% & Sop 2 \% & SEM & P value \\
\hline Antibody titers against ND ( 7 day) & 2.0 & 1.95 & 2.0 & 2.3 & 0.07 & 0.4 \\
Antibody titers against ND( 14 day) & $1.56^{\mathrm{b}}$ & $1.97^{\mathrm{ab}}$ & $1.97^{\mathrm{ab}}$ & $2.3^{\mathrm{a}}$ & 0.09 & 0.05 \\
Antibody titers against sRBC( 7 day) & $1.54^{\mathrm{c}}$ & $2.0^{\mathrm{cb}}$ & $2.55^{\mathrm{ab}}$ & $2.6^{\mathrm{a}}$ & 0.14 & 0.004 \\
Antibody titers against sRBC(14 day) & $1.58^{\mathrm{b}}$ & $2.0^{\mathrm{ab}}$ & $2.1^{\mathrm{a}}$ & $2.65^{\mathrm{a}}$ & 0.12 & 0.01 \\
$\begin{array}{l}\text { Cell mediate immunity response(toe web } \\
\text { thickness) after 24 h }\end{array}$ & $1.46^{\mathrm{c}}$ & $1.9^{\mathrm{a}}$ & $1.6^{\mathrm{b}}$ & $1.7^{\mathrm{b}}$ & 0.04 & 0.01 \\
$\begin{array}{l}\text { Cell mediate immunity response(toe web } \\
\text { thickness) after 48 h }\end{array}$ & $1.65^{\mathrm{c}}$ & $2.17^{\mathrm{a}}$ & $2.0^{\mathrm{b}}$ & $2.1^{\mathrm{ab}}$ & 0.04 & 0.01
\end{tabular}

${ }^{\mathrm{a}-\mathrm{b}}$ values with different small letter superscripts within the same row indicate significant differences, ${ }^{1}$ values are the means of 4 pens of two birds per pen ( 8 birds / treatment), SEM : Standard error mean, ${ }^{2}$ control: basal diet, vit C : basal diet $+500 \mathrm{mg}$ vitamin C / $\mathrm{kg}$ feed (500 ppm); Sop 1\%: basal diet $+1 \%$ of Citrus sinensis as feed additive ; Sop $2 \%$ : basal diet $+2 \%$ of Citrus sinensis as feed additive.

\section{References}

1. Soleimani AF, Zulkifli I, Omar AR, Raha AR..Physiological responses of three chicken breeds to acute heat stress. Poul Sci. 2011;90:309-336.

2. Aksit M, Yalcin S, Ozkan S, Metin K, Ozdemir D, Effects of temperature during rearing and crating on stress parameters and meat quality of broilers. Poult Sci. 2006;85:1867-1874.

3. Yazad MAK, Kikusato M, Maekawa T, Shirakawa H, Toyomizu M.. Metabolic characteristics and oxidative damage to skeletal muscle in broiler chickens exposed to chronic heat stress. Comparat Bioch Physiol Part A: Molecular \& Integrative Physiol. 2010;155(3):401406.

4. Bozkurt M, Kucukvilmaz K, Catli AU, CinarM, Bintas E, Coven F. Performance, egg quality, and immune response of laying hens fed diets supplemented with manna-oligosaccharide or an essential oil mixture under moderate and hot environmental conditions. Poult Sci. 2012; 91:1379-1386.

5. Al-Fataftah, AA, Abu-Dieyeh, ZHM.. Effect of chronic heat stress on broiler performance in Jordan. Int J Poult. Sci. 2007;6(1):64-70.

6. Cristiane FP, Marchini MA.. Phsiological, cell dynamics of small intestinal mucosa and performance of broiler chickens under heat stress. Areview,Rev Colomb Ciene Pecu. 2016; 29:159-168.

7. Acker D, Cunningham M.. Animal science and industry. PrenticeHall.Upper Saddle River. NewJersy. 1998:pp:189-195.

8. Gonzalez-Esquerra R, Leeson S.. Physiological and metabolic responses of broilers to heat stress-implications for protein and amino acid nutrition. World's Poult Sci J. 2006;62(2):282-295.

9. Oliveira GA, Oliveira DFM, Donzela frango JL, Cecon PR, Vaz RGMV, Orlando, UAD. Efeito da temperature ambiente sorbre o desempenbo e as caracteristicas de carcaca rangos de corte dos 22 aos42 dias Revista Brasileira de Zootecnia,. R Bras Zootec. 2006; 35:1398-1405(abstract).

10. Raeisi-Zeydabad S, Mirmahoudi R,.Esmaeilipour O, Mazhari M. Effect of Coenzyme Q10 and Vitamin C on growth performance and blood components in broiler chickens under heat stress. Poult Sci J. 2017;5(2):145-152.

11. Sahin N, Tuzcu M, Orhan C, Onderci M, Eroksuz Y, Sahin K. The effects of vitamin $\mathrm{C}$ and $\mathrm{E}$ supplementation on heat shock protein 70 response of ovary and brain in heat-stressed quail. Brit poult Sci.009;50(2):259-265.

12. Zimbelman, RB, Baumgard LH, Collier RJ. Effects of encapsulated niacin on evaporative heat loss and body temperature in moderately heat-stressed lactating Holstein cows. J Dairy Sci. 2010;93(6):23872394.
13. Guo WJ, Zhen L, Zhang JX, Lian S, Si HF, Guo JR, Yang HM. Effect of feeding Rumen-protected capsule containing niacin, K2SO4, vitamin $\mathrm{C}$, and gamma-aminobutyric acid on heat stress and performance of dairy cows. J therm Boil. 2017;69:249-253.

14. Gursu MF, Onderci M, Gulcu F, Sahin K, Effects of vitamin C and folic acid supplementation on serum paraoxonase activity and metabolites induced by heat stress in vivo. Nutrit Res. 2004;24(2):157-164

15. Yang XY, Xie JX, Wang FF, Zhong J, Liu YZ, Li GH, Peng SA. Comparison of ascorbate metabolism in fruits of two citrus species with obvious difference in ascorbate content in pulp. J plant physiol. 2011;168(18):2196-2205.

16. Ani AO, Iloh EA, Akinsola OO. Dietary effect of processed orange peels on growth performance of broiler finisher birds. Brit J Applied Sci Technol. 2015;9(6):576-583.

17. Ebrahimi A, Qotbi AAA, Seidavi A, Laudadio V, Tufarelli V. Effect of different levels of dried sweet orange (Citrus sinensis) peel on broiler chickens growth performance. Arch Animal Breed. 2013;56(1):11-17.

18. Broiler Nutrition Specifications. Ross 308 Broiler Nutrition Specifications.Aviagen Company, Scotland. 2007.

19. Wegmann TG, Smithies O. A simple hemagglutination system requiring small amounts of red cells and antibodies. Transfusion. 1966;6(1):67-73.

20. SPSS: SPSS/PC +, for the PC/XT. SPSS INC. 2001

21. Abdel-Hack ME, Attia AI, Arit M, Soomro RN, Arain MA. The impacts of dietary Nigella meal and Avizyme on growth, nutrient digestibility and blood metabolites of meat type quail. Animal Prod Sci. 2016;58(2):291-298.

22. Abbasi H, Seidavi A, Liu W, Asadpour L. Investigation on the effect of different levels of dried sweet orange (Citrus sinensis) pulp on performance, carcass characteristics and physiological and biochemical parameters in broiler chicken. Saudi J boil Sci. 2015;22(2):139-146.

23. Agu PN, Oluremi OIA, Tuleun CD. Nutritional evaluation of sweet orange (Citrus sinensis) fruit peel as feed resource in broiler production. Int J Poult Sci. 2010;9(7):684-688.

24. Ayed MH, Zghal I, Rekik B. Effect of sepiolite supplementation on broiler growth performances and carcass yield. Res Opin Anim Vet Sci. 2011;1(6);375-378

25. Soltani A, Pourreza J, Kheiri F, Faghani M. Effect of partially substituted barley malt on performance, bone ash, calcium and phosphorus of broiler chickens. Res Opin Ani Vet Sci. 2012;2:133135.

26. Basir R, Toghyani M. Effect of dietary graded levels of dried lemon (citrus aurantifulia) pulp on performance, intestinal morphology, and 
humoral immunity in broiler chickens. Inte J Recycling of Organic Waste in Agricult. 2017;6(2):125-132.

27. Serena A, Hedemann MS, Knudsen KB. Feeding high fibre diets changes luminal environment and morphology in the intestine of sows. Livestock Sci. 2007;109(1):115-117.

28. Oluremi OIA, Okafor FN, Adenkola AY, Orayaga KT. Effect of fermentation of sweet orange (Citrus sinensis) fruit peel on its phytonutrients and the performance of broiler starter. Inter J Poult Sci. 2010;9(6):546-549.

29. Alzawqari MH, Al-Baddany AA, Al-Baadani HH, Alhidary IA, Khan RU, Aqil GM, Abdurab A.. Effect of feeding dried sweet orange (Citrus sinensis) peel and lemon grass (Cymbopogon citratus) leaves on growth performance, carcass traits, serum metabolites and antioxidant status in broiler during the finisher phase. Env Sci Poll Res. 2016;23(17):17077-17082.

30. Langhout, DJ, Schutte JB. Nutritional implications of pectins in chicks in relation to esterification and origin of pectins. Poult Sci.1996;75(10):1236-1242.

31. Langhout DJ, Schutte J, Van B, Leeuwen P, Wiebenga J, Tamminga S. Effect of dietary high-and low-methylated citrus pectin on the activity of the ileal microflora and morphology of the small intestinal wall of broiler chicks. Brit Poult Sci. 1999;40(3):340-347.

32. Hon FM, Oluremi OIA, Anugwa FOI. The effect of dried sweet orange (Citrus sinensis) fruit pulp meal on the growth performance of rabbits. Pakist J Nutrit. 2009;8(8):1150-1155.

33. Mukhtar A, Mohamed K, Amal O, Ahlam A. Effect of different levels of lemon grass oil (lgo) as anatural growth promoter on the performance, carcass yields and serum chemistry of broiler chicks. Egypt Poult Sci. 2012;33:1-7.

34. Pourhossein Z, Qotbi, AAA, Seidavi A, Laudadio V, Centoducati G, Tufarelli V.. Effect of different levels of dietary sweet orange (Citrus sinensis) peel extract on humoral immune system responses in broiler chickens. Ani Sci J. 2015;86 (1):105-110.

35. Ojabo, LD, Oluremi OIA, Carew SN, Uza DV. Heamatology and serum biochemistry of pullet grower chickens fed sweet orange (Citrus sinensis) fruit peel meal based diets. Res Opini Anim Vet Sci. 2013;3(8):252-256.

36. Nobakht A. Effects of different levels of dried lemon (Citrus aurantifulia) pulpon performance, carcass traits, blood biochemical and immunity parameters of broilers. Iran. J Appl Anim Sci. 2013;3(1):145-151.

37. Anagnostopoulou MA, Kefalas P, Kokkalou E, Assimopoulou AN, Papageorgiou VP. Analysis of antioxidant compounds in sweet orange peel by HPLC-diode array detection-electrospray ionization mass spectrometry. Biomed Chromatog. 2005;19(2);138-148.

38. Tirkey N, Pilkhwal S, Kuhad A, Chopra K. Hesperidin, a citrus bioflavonoid, decreases the oxidative stress produced by carbon tetrachloride in rat liver and kidney. BMC Pharmacol. 2005;5(1):2.

39. Abdulameer YS, Modirsanei M, Kiaei1 MM, Mansoori1 B, Farkhoy M. The Effect of Early Feeding and Feed Additives on Lymphoid Organs, Intestinal Microbiology and Meat Peroxidation of Broiler. Life Sci J. 2016;13(7):31-40.

40. Boa-Amponsem K, Price SE, Picard M, Geraert PA, Siegel PB.Vitamin E and immune responses of broiler pureline chickens. Poult Sci. 2000;79(4):466-470.

41. Sadeghi A,Toghyani M, Gheisari A. Effect of various fiber types and choice feeding of fiber on performance, gut development, humoral immunity, and fiber preference in broiler chicks. Poult Sci. 2015;94(11): 2734-2743 